Uniwersytet w Białymstoku

Wydział Filologiczny

tel. +48857457446

e-mail: olakowalewska@interia.pl

\title{
Kto powiedział, że chłopaki nie płaczą, a dziewczynki są zawsze miłe? O normatywnym charakterze pewnych typów zdań gatunkowych
}

Słowa kluczowe: norma, normatywność, normy pozaprawne, generalizacje, referencja gatunkowa

\section{Wstęp}

Generalizacje są obszarem stosunkowo słabo zbadanym na gruncie językoznawstwa polskiego, o czym świadczy niezbyt duża liczba publikacji poświęconych temu zagadnieniu ${ }^{1}$. Co więcej, problem normatywnego charakteru uogólnień dotyczących określonych (wyrazistych) gatunków społecznych został podniesiony dość niedawno w językoznawstwie anglosaskim (Leslie 2015). Kolejnym argumentem za podjęciem tak sformułowanego tematu badań jest interesująca kwestia ujawniającej się w języku sytuacji społecznej kobiet. Od publikacji poruszającej ten temat przełomowej pracy Robin Lakoff (Lakoff 1975) minęło ponad 40 lat. Biorąc pod uwagę rozmiar i charakter zmian społecznych, jakie dokonały się w ciągu tego okresu, eksploracja

1 Dwie najobszerniejsze rodzime publikacje na ten temat to prace Agnieszki Gasz (2013) i Daniela Karczewskiego (2016). Zjawisko generyczności doczekało się liczniejszych publikacji anglojęzycznych prezentujących wyniki badań filozofów reprezentujących nurt analityczny oraz językoznawców z kręgu lingwistyki kognitywnej. 
zagadnienia normatywności zdań interpretowanych jako generyczne wydaje się być interesującym wyzwaniem badawczym, szczególnie jeśli badania oparte są na przykładzie funkcjonowania takich wypowiedzi w kontekstach, gdzie aktywne są ramy pojęciowe dotyczące ról przypisywanych kobietom.

\section{Zarys problemu, cel badawczy, metodologia, materiał}

Odwoływanie się do określonych założeń oceniających (przy założeniu spójnego systemu wiedzy i ocen) może być traktowane jako symptom określonej sytuacji społecznej, w której oceny te funkcjonują i są powszechnie uznawane za słuszne. Co za tym idzie, z tego jakie są oceny można wnioskować o kulturze i systemie wartości danego obszaru językowego. Uzasadnione zatem wydaje się przyjęcie złożonego celu badawczego, jakim jest opis generalizacji interpretowanych jako generyczne z uwzględnieniem problemów dodatkowych. Problemy te obejmowałaby kwestię normatywności wypowiedzi oraz ukrytej normatywności wypowiedzi ogólnych (a ściślej: generycznych) dotyczących kategorii o charakterze dwoistym (ang. dual character concepts $)^{2}$ obejmującej wyraziste kulturowo i konotacyjnie gatunki społeczne. Jako że rzetelność opisu wymaga eksplikacji, zostanie on oparty na przykładzie wybranych wyrazistych gatunków społecznych, których elementem wspólnym jest rama pojęciowa kobiety. Narzędziem do osiągnięcia tak pomyślanego celu ma być analiza korpusowa tekstów pochodzących z polskich edycji prasy kobiecej (opiniotwórczych tytułów czasopism, adresowanych do reprezentatywnej grupy kobiet: wykształconych, niezależnych zawodowo i finansowo, odnoszących sukces lub do tego aspirujących, reprezentujących wszystkie grupy wiekowe i średnią - do wyższej - klasę społeczną). W dalszej kolejności analiza prowadzić ma do wyodrębnienia wyrażeń oceniających i powinnościowych formułujących pewne normy dotyczące postaw i przekonań oraz norm postępowania w sytuacjach społecznych. „Słuszność” czy „prawdziwość" takich norm, jako zgodnych ze zbiorem ogólnie akceptowanych zasad, może być im przypisana dzięki założeniu, że struktura logiczna języka i siła motywacyjna tychże norm jest zgodna ze strukturą ontologiczną świata, to zaś umożliwia uzasadnienie aksjologiczne norm na gruncie ocen i wiedzy przypisywanych normodawcy oraz intuicji potocznych ujawniają-

2 Termin zaproponowany przez Knobego, Prasadę i Newmana (Knobe, J., Prasada, S. i Newman, G. (2013), Dual Character Concepts and the Normative Dimension of Conceptual Representation, „Cognition”, 127, s. 242-257). 
cych się $\mathrm{w}$ języku ${ }^{3}$. Przyjmując istnienie spójnego systemu wiedzy i ocen, opieranie się na określonych założeniach oceniających może być traktowane jako symptom sytuacji społecznej, w której działa normodawca. Analiza wybranych tekstów ma na celu wyodrębnienie zarówno obszarów regulowanych normami, jak i wypowiedzi będących nośnikami owych norm, przy czym normy te traktowane są jako wyraz oczekiwań społecznych wobec kobiet. Co więcej, tak rozumiane normy mają potencjalny wpływ na kształtowanie się przekonań kobiet co do własnej roli (a w konsekwencji na ich reakcje $\mathrm{w}$ określonych sytuacjach społecznych regulowanych badanymi normami). $\mathrm{Z}$ racji tego, że chodzi o normy regulujące funkcjonowanie gatunków społecznych, zakłada się, że mają one charakter pozaprawny i jako takie wyrażają sądy normatywne w sposób pośredni (niejawny) bez pośrednictwa usankcjonowanej i rozpoznawalnej formy językowej (funktora deontycznego). W tak zaprojektowanych badaniach przyjmuje się perspektywę badawczą i metodologię możliwą do wypracowania w ramach założeń teoretycznych proponowanych przez filozofię analityczną i fenomenologię lingwistyczną Johna L. Austina, z odwołaniem się do określonych aspektów językoznawstwa kognitywnego. Taki a nie inny wybór uzasadniony jest postulatem, że analiza języka może ujawnić pewne reguły dotyczące świata (spójność struktury logicznej języka z ontologiczną strukturą świata, rola języka potocznego i języka w działaniu, świat a reprezentacje mentalne).

Podsumowując, studium oparte jest o następujące tezy:

(a) Pewnego rodzaju generalizacje o strukturze składniowej typowej dla wypowiedzi deskryptywnych wykazują siłę normatywną.

(b) Użytkownicy języka wykazują tendencję do generycznego interpretowania uogólnień dotyczących pewnych kategorii społecznych, do których przypisane są określone role. Kategorie wyraziste kulturowo i konotacyjnie cechuje dwoistość wyrażająca się polisemią grupy imiennej oraz rozłącznym przysługiwaniem normatywnych i deskryptywnych kryteriów klasyfikacji.

3 W przypadku norm pozaprawnych, ujawniających się w intuicjach potocznych, również mamy do czynienia z normodawcą: normy składające się na zbiór ogólnie przyjętych przez daną zbiorowość zasad usankcjonowane są autorytetem aprobującej je społeczności, normodawcą zaś jest ten, kto normy stanowi na mocy przyznanego mu autorytetu lub uprawnienia; normodawcą może być ustawodawstwo, zwyczaj, natura rzeczy, idea dobra czy sprawiedliwości (normy heteronomiczne), a nawet sama jednostka, która wyraża wolę stosowania się do narzuconej sobie normy (norma autonomiczna). Naturalna potrzeba porządkowania i opierania się na kodeksach ujawnia się w utartych wyrażeniach potocznych w rodzaju Gdzie tak jest napisane czy Kto tak powiedziat odwołujących się do jakichś bliżej nieokreślonych, lecz funkcjonujących w świadomości społecznej zbiorach reguł, zasad, zaleceń, zakazów i nakazów, i stojących za nimi normodawców. 
(c) Negacja jest istotnym czynnikiem kształtującym rozumienie wypowiedzi.

(d) Normatywne uogólnienia generyczne, dotyczące kobiet, mogą ujawniać się $\mathrm{w}$ obecnych w prasie kobiecej kontekstach dotyczących stylu życia. Wyprowadzone z takich kontekstów normy mogą przenikać do języka potocznego, mogą też mieć istotny wpływ na postrzeganie przez kobiety ich własnej roli, kształtowanie się ich przekonań oraz zachowania językowe i społeczne.

Niniejsza praca, z uwagi na ograniczony zakres, koncentruje się na jednym z aspektów omówionych wyżej badań, a mianowicie na zagadnieniu normatywności uogólnień dotyczących kategorii o charakterze dwoistym (ściślej: wyrazistych gatunków społecznych), co odpowiada ogólnemu zarysowi problematyki, której dotyczą tezy (a) i (b).

\section{Norma i normatywność wypowiedzi. Zdania opisowe, normatywne, wartościujące}

W opisie uogólnień normatywnych kluczowe zdają się być rozróżnienia w obrębie dwóch obszarów: (i) normy, oraz (ii) zdań opisowych i zdań normatywnych oraz związanej z nimi ściśle kwestii znaczeń (sensów) deskryptywnych, normatywnych i wartościujących. Termin norma $a^{4}$ wydaje się niejasny ze względu na wieloznaczność wynikającą z wielości dziedzin, w których się je stosuje; wieloznaczność tę często próbuje się niwelować poprzez dookreślanie terminu przymiotnikiem wskazującym dziedzinę, w której ma ona zastosowanie (norma moralna, techniczna, religijna, prawna, zwyczajowa) lub synonimem (standard, reguła, przepis). Zauważyć jednak trzeba, że wieloznaczność pojęcia normy nie jest jedynie kwestią zróżnicowania regulowanych nią obszarów, ale wynika też z polisemii terminu ogólnego: norma rozumiana jako pożadany standard i dotycząca charakterystyki i repertuaru pewnych właściwości jest zatem czymś innym niż dyrektywa określająca wytyczne do działania, podobnie, pomimo pozornego podobieństwa, norma postępowania różni się od normy dotyczacej systemu przekonań; za najważniejszą w świetle rozważań nad językową formą znaczeń generycznych można jednak przyjąć opo-

\footnotetext{
4 Wyczerpująca definicja normy, podobnie jak opis jej typów, różnicy między normą społeczną i prawną, czy specyfika językowej formy tej ostatniej wykraczają poza zakres niniejszego artykułu; podobnie rzecz ma się w przypadku szeroko pojętego znaczenia normy spotecznej.
} 
zycję normy wtaściwej odnoszącej się do istniejącego, uporządkowanego, ujednoliconego, „normalnego" stanu rzeczy wobec normy idealnej postulującej wyidealizowany stan pożądany. Nadto, norma i normatywność zazwyczaj częściej i naturalniej kojarzy się z dyskursem prawnym, stąd też w rozważaniach nad normatywnością zdań w rodzaju Chtopaki nie ptacza konieczne jest posługiwanie się pojęciem normy pozaprawnej. Problem normy jako formy wypowiedzi w polskojęzycznej literaturze przedmiotu podejmują m.in. Tadeusz Kotarbiński i Jerzy Kalinowski. Zarówno Kotarbiński, jak Kalinowski budują definicję zdania normatywnego ${ }^{5}$, przy czym Kalinowski umiejscawia je w kategorii zdań praktycznych ${ }^{6}$. Istotne jest to, że Kalinowski dzieli zdania praktyczne na dwa zbiory odpowiadające dwóm poziomom języka7. W grupie pierwszej znajdują się zdania rozkazujące, wartościujące i normatywne oraz zdania o tychże zdaniach. Według klasyfikacji Kalinowskiego, zdania wartościujące (Mówienie prawdy jest moralnie dobre) rozumiane są jako zdania przyznające działaniu ludzkiemu wartość praktyczną (dobro, zło, ekonomiczność, solidność) lub jej odmawiające, natomiast zdania normatywne (Każdy obywatel powinien płacić podatki), które pod względem składniowym są wyrażającymi zalecenie zdaniami orzekającymi zbudowanymi za pomocą wy-

5 Kotarbiński przez zdania normatywne rozumie wypowiedzi o charakterze rozkazów, rad, czy ostrzeżeń, czemu sprzeciwia się Kalinowski, odróżniając zdania normatywne od innych rodzajów zdań praktycznych, zaś analizowane przez Kotarbińskiego jako normatywne zdania w rodzaju „Aby stało się to a to, niezbędne jest takie a takie zachowanie się czynne”, „takie a takie postępowanie byłoby wstrętne” (Kotarbiński 1986, s. 354) uznaje za „oceny utylitarne”, nie zaś normy (Kalinowski 1960). Poglądy Kalinowskiego, podobnie jak zagadnienie semantyki i logiki deontycznej wyłożone są szczegółowo w publikacji Roberta Trypuza (2004).

6 Zdania praktyczne (wyrażające to, jak być powinno) stoją w opozycji do zdań teoretycznych (wyrażających to, jak jest). Kalinowski (1960) przedstawia charakterystykę składniowo-semantyczną wszystkich trzech typów zdań praktycznych, z której wynika, że normy mogą być wyrażone również przez wypowiedzi rozkazujące i wartościujące, zaś do przyporządkowania zdania do określonego typu niewystarczające jest opieranie się na jednym jedynie rodzaju kryteriów (składniowym bądź semantycznym), zdanie bowiem może - dla przykładu - syntaktycznie nie spełniać wymagań klasyfikacyjnych, a jednak semantycznie bezsprzecznie wyrażać określony sens: rozkaz może być wyrażony wypowiedzią o budowie pytania (Dlaczego w mieszkaniu pala się wszystkie światta? ) bądź gestem. Konstatacja ta wyraźnie implikuje zasadność oparcia analizy o założenia pragmatyki językowej i teorii performatywów. W tym kontekście konieczne jest podkreślenie różnicy pomiędzy normą jako konstatacją sądu normatywnego a zdaniem normatywnym, będącym językowym wykładnikiem stosunku normatywnego.

7 Zdania wyrażające sądy normatywne oraz zdania o normach jako przedmiot logiki norm, logiki deontycznej i semantyki deontycznej z racji podejmowanej przez te dyscypliny problematyki wykraczają poza przyjęty tu zakres rozważań; szerzej na ten temat: Trypuz (2003), Kalinowski (1993), von Wright (1951, 1963, 1964, 1968), Ziemba (1969, 1983), Ziembiński (1964, 1998), Woleński (1966) [w:] Trypuz (2004). 
rażeń w formie osobowej $X$ powinien (nie) czynić $X, X$ ma prawo (nie) czynić $X, X$ wolno (nie) czynić $X, X$ można (nie) czynić $X$ (Kalinowski 1953, 114); w miejsce $\mathrm{X}$ wstawiamy odpowiednio nazwy podmiotów działających oraz nazwy działań; semantycznie stanowią one znak językowy sądu normatywnego (Trypuz 2004, 3). W grupie drugiej, co znamienne, Kalinowski umieszcza „(...) zdania mówiące bezpośrednio o podmiocie działania (a jedynie pośrednio o działaniu) wartościującym, normującym czy nakazującym działanie jakiegoś podmiotu działania. Do tej grupy należą zdania wyrażające: życzenia, prośby, błagania, zachęty, ostrzeżenia, rady, itp., na przykład: Życze sobie „Wyjdź stad”, Zachęcam cię „przeczytaj te ksiażke"; zdania przypisujące zdaniom: wartościującym, rozkazującym i normatywnym pewne własności, analizują je, wyjaśniają, uzasadniają; zdania wyrażające obietnice i groźby; zdania dostarczające wiedzy potrzebnej do uznania pewnych zdań: wartościujących, rozkazujących i normatywnych; zdania, które kierują działaniem ludzkim ze względu na intencję wypowiadającego je i okoliczności, w których to czyni" (Trypuz 2004, 2-3).

W kontekście problematyki zdań ogólnych o charakterze normatywnym (czyli praktycznego funkcjonowania wypowiedzi, które formalnie nie będąc zdaniami normatywnymi wykazują jednak siłę normatywną) najbardziej istotne zdają się być różnica między wypowiedziami wartościującymi i normatywnymi (z uwzględnieniem relacji tych dwóch typów zdań do zdań opisowych), oraz pojęcia normatywne: zakazany, nakazany, dozwolony, fakultatywny, indyferentny, których znaczenie ujawnione w interpretowanych wypowiedziach nie wyrażających otwarcie stosunku powinnościowego umożliwia wyprowadzanie norm z faktów w zdaniach ogólnych będących przedmiotem opisywanych dociekań.

Związek pomiędzy zdaniami opisowymi a normatywnymi zdaje się być jasny, rozpoznawalny i nie budzący wątpliwości: zdania opisowe opisują relacje pomiędzy faktami, czyli tym, co jest, zdania normatywne natomiast koncentrują się na opisie tego, co lub jak być powinno; oba typy zdań należą do domeny rozumu. Zdania wartościujące, podobne normatywnym w tym, że nie odnoszą się do faktów, nie należą jednak do domeny rozu$\mathrm{mu}$, a do domeny emocji, bowiem ujawnia się $\mathrm{w}$ nich preferencja wobec jakiegoś stanu rzeczy lub faktu. Wypowiedzi wartościujące, choć nie wyrażają norm w sposób bezpośredni, stanowią wyraz aprobaty lub dezaprobaty wobec jakiegoś zbioru zasad czy standardów ustalonych przez społeczność. Predykaty oceniające, takie jak dobry, porzadny, piękny czy wtaściwy z racji swojej subiektywności są nieostre. Nieostrość polega na tym, że niemożliwe jest sformułowanie definicji określającej uniwersalnie praw- 
dziwy zestaw cech, jakimi charakteryzuje się obiekt, któremu dany predykat przypisuje określoną wartość. Funkcjonuje pogląd, że orzeczniki wartościujące nie odnoszą się do cech obiektywnie przysługujących obiektom, ale do cech postrzeganych lub pomyślanych jako tym obiektom przysługujące ${ }^{8}$. Intuicje potoczne charakteryzuje to, że mogą one być formułowane na podstawie jedynie znajomości funkcjonowania danych cech $\mathrm{w}$ języku, z pominięciem znajomości znaczenia predykatów oceniających. Taka właściwość języka potocznego sprawia, że możliwe jest powstawanie uogólnień stereotypowych, których znaczenia się nie podważa pomimo świadomości faktu, że nie są to prawdy uniwersalne i zbudowane są na podstawie wiedzy potocznej, a nie naukowej. Właściwość ta, podobnie jak specyfika użycia modyfikatorów jakościowych prawdziwy i dobry przypomniana zostanie w dalszej części pracy. Wypowiedzi wartościujące mogą pełnić inne funkcje, które nie są rozpoznawalne na podstawie ich cech formalnych: przyjmuje się, że wyrażają one wewnętrzne stany wypowiadającego, ale mogą też nakłaniać do pewnych działań lub wywoływać określone stany. Dla przykładu, zdanie Szpinak jest zdrowy wyraża wewnętrzne przekonanie wypowiadającego, ale może też oznaczać życzenie (Chciałabym, żebyś zjadt ten szpinak) rozkaz (Zjedz szpinak) czy powinność (Kto chce być zdrowy powinien jeść szpinak). Ten ostatni przykład rozwinąć można w sposób następujący:

(a) Szpinak jest zdrowy.

(b) Szpinak jest dobrym pożywieniem bo jest dobry dla zdrowia.

(c) Należy jeść szpinak by być zdrowym.

(d) Każdy kto/Ten kto chce być zdrowy powinien jeść szpinak.

Powyższy przykład wskazuje, że wypowiedzi wartościujące można podzielić na dwie grupy, mianowicie (i) takie, które stanowią definicję projektującą terminu dobry ${ }^{9}$ i ustalającą jego znaczenie $\mathrm{w}$ danym języku (dobre sa takie przedmioty, które maja następujace cechy Z), oraz (ii) wypowiedzi quasi-normatywne będące rezultatem wartościowania wtórnego (przedmiot $X$ jest dobry ze względu na cechy Z).

8 Dyskusja na temat stosunku wartości do innych cech , podziału cech na pierwotne i wtórne (poznawane dzięki zmysłom a zatem subiektywne) i poglądu, że wartości są subiektywnymi własnościami przedmiotów wykracza poza zakres rozważań przyjęty w niniejszej pracy (więcej na ten temat: m.in. John Locke $(1690,1955)$ Rozważania dotyczace rozumu ludzkiego, tł. B.J. Gawecki, Warszawa).

9 Dobro i prawda oraz ich derywaty dobry i prawdziwy stanowią część przedmiotu przedstawionych we Wstępie badan, ich opis wykracza jednak poza zakres niniejszego artykułu. 
W tym miejscu warto podsumować różnice między zdaniem normatywnym a zdaniem wartościującym o ukrytym charakterze normatywnym:

\begin{tabular}{|l|l|l|l|}
\hline Zdanie normatywne & $\begin{array}{l}\text { nie stwierdza } \\
\text { faktu }\end{array}$ & $\begin{array}{l}\text { nie ma znaczenia } \\
\text { referencjalnego }\end{array}$ & $\begin{array}{l}\text { odwołuje się do zbioru } \\
\text { zasad ustalonych przez } \\
\text { umocowanego do tego } \\
\text { normodawcę }\end{array}$ \\
\hline $\begin{array}{l}\text { Zdanie wartościujące } \\
\text { o charakterze } \\
\text { normatywnym }\end{array}$ & $\begin{array}{l}\text { stwierdza } \\
\text { fakt }\end{array}$ & $\begin{array}{l}\text { ma znaczenie } \\
\text { referencjalne }\end{array}$ & $\begin{array}{l}\text { odwołuje się do } \\
\text { „powszechnego uznania } \\
\text { za słuszne” }\end{array}$ \\
\hline
\end{tabular}

\section{Charakterystyka wypowiedzi ogólnych i generycznych}

Przedmiotem analizy omawianej w niniejszej pracy są wypowiedzi generyczne, będące jednym z typów wypowiedzi ogólnych ${ }^{10}$, i jako takie są one produktem procesu uogólniania. Dokładnego przeglądu definicji generalizacji sformułowanych na gruncie dociekań językoznawczych, filozoficznych, logicznych czy psychologicznych dokonuje Agnieszka Gasz (2013). W „Zarysie gramatyki uogólnień" jej autorstwa czytamy między innymi, że „[u]ogólnianie (generalizacja) spostrzeżeń jest nieodłącznym elementem myślenia, które umożliwia ujmowanie ogólnych cech rzeczy odnoszących się do całych grup przedmiotów i zjawisk" (Gasz 2013, 10). Proces ten jest niezbędny, by umysł potrafił uporządkować nieprzebrane bogactwo i chaos rzeczywistości, upraszczając ją poprzez doszukiwanie się w niej praw ${ }^{11}$. Wedle Renaty Grzegorczykowej ${ }^{12}$, systematyzacja wiedzy polega na wyróżnianiu pewnych klas (kategorii) oraz ich przedstawicieli i określaniu ich wspólną nazwą na podstawie pewnych istotnych dla nich cech. Tworzone

10 Z uwagi na wyraźnie określony tematu artykułu, wywód koncentruje się na charakterystyce wypowiedzi generycznych z pominięciem szczegółowego opisu zdań ogólnych, który znaleźć można między innymi w publikacjach Renaty Grzegorczykowej (2001), Agnieszki Gasz (2013) czy Daniela Karczewskiego (2015), nie wspominając o licznych opracowaniach anglojęzycznych.

11 Zob. W. Tatarkiewicz (1988), Nietzsche, [w:] tegoż, Historia filozofii, T. 3, s. 164-165.

12 Zob. Grzegorczykowa, R. (1978), O generycznym użyciu nazw, Polonica, nr 4, s. 73-76, oraz tejże: (1991) Rola jezyka w tworzeniu kultury umysłowej, [w:] Jezzy a Kultura, T1, red. J. Anusiewicz, J. Bartmiński, Wrocław, s. 64; oraz tejże: Problemy dyskusyjne w opisie zjawiska referencji, [w:] Études de linguistique Romane et Slave, red. W. Banyś, L. Bednarczuk, K. Bogacki, Kraków, s. 271-282. 
w taki sposób sądy ogólne są uproszczeniami, gdyż uwzględniają one cechy właściwe wszystkim reprezentantom danej klasy, lub przeważającej jej części, nie opierają się jednak na naukowych dowodach popartych liczbami. Można w tym miejscu zauważyć, że precyzja uogólniania jest stopniowalna, stąd podział generalizacji na ścisłe i niewłaściwe, inaczej nazywane uogólnieniami w stereotypie (Gasz 2013, 12). Precyzja uogólnień nie jest weryfikowalna ze względu na niedopowiedzenia kwantyfikacji ${ }^{13}$ oraz wieloznaczność i nieostrość terminów określających cechy orzekane przez predykat (Hołówka 1986, 52), co jest szczególnie wyraźne w przypadku uogólnień potocznych opartych na stereotypie i obejmujących niewielką liczbę przypadków. Według Teresy Hołówki, uogólnienia w stereotypie pełnią niezwykle ważną funkcję komunikacyjną, służąc jako środek do osiągnięcia założonego przez nadawcę celu, którym jest propagowanie, upowszechnianie czy narzucanie pewnych postaw, światopoglądu czy systemu wartości ${ }^{14}$. Operowanie ogólnikami pozwala też na obejście tematów trudnych czy drażliwych za pomocą przenoszenia cech jednostki na całą klasę (por. Dlaczego kobiety wszystkim sie przejmuja zamiast Dlaczego ty wszystkim sie przejmujesz) ${ }^{15}$.

Kwestia stopnia precyzji uogólnień, stereotypów i perswazyjnego użycia kwantyfikatorów jest warta zaznaczenia ze względu na problematykę opisywanych badań, czyli normatywnego charakteru zdań generycznych. Sam mechanizm tworzenia nazw generycznych (gatunkowych) orzekających coś o całej klasie obiektów nazwanej nazwą ogólną w dużym uproszczeniu określić można jako orzekanie pewnej własności w odniesieniu nie do każdego X czy wszystkich X, a X uogólnionego do całego gatunku ${ }^{16}$. Agnieszka Gasz (2013) podkreśla, że z punktu widzenia logiki nazwa jest tu użyta w supozycji formalnej. Klasyfikowanie i kategoryzacja ${ }^{17}$ oraz spór o rodzaj cech stanowiących podstawę przypisania obiektu do danego zbioru (czy są to cechy istotne, esencjalne, czy typowe) stanowią podstawe podziału zdań

13 Generalizacje opierają się na opozycji kwantyfikatorów każdy-wszyscy-nikt.

14 Zob. J. Bartmiński, J. Panasiuk (1993), Stereotypy językowe, [w:] Encyklopedia kultury polskiej XX wieku, T. 2. red. J. Bartmiński (za: Gasz 2013).

15 Mechanizmy perswazyjnego potęgowania ilości omawia Jerzy Bralczyk (Bralczyk, J. (2000), „Język na sprzedaż”, Warszawa-Bydgoszcz).

16 Zob. A. Bednarek, M. Grochowski (1993), Zadania z semantyki językoznawczej, Toruń, s. 52 .

17 Zdaniem Grażyny Habrajskiej, kategoryzacja i klasyfikacja nie są pojęciami tożsamymi; kategoryzacja opiera się na cechach stereotypowych, a klasyfikacja - na cechach kategorialnych (Habrajska, G. (1996), Kategoryzacja a klasyfikacja-potoczne i naukowe widzenie świata, [w:] Językowa kategoryzacja świata, red. R. Grzegorczykowa, A. Pajdzińska, Lublin, s. 222, za: Gasz 2013). 
ogólnych o referencji gatunkowej na generyczne (np. Pies jest ssakiem) i typizujące (Psy lubia kości), przy czym - jak stwierdzają Jerzy Bartmiński i Ryszard Tokarski - wewnętrzne uporządkowanie opisu zależy od wyboru językowego obrazu świata: naukowego (uogólnienia ścisłe) lub potocznego (uogólnienia stereotypowe). Wskazana różnica widoczna jest też w budowie i użyciu grupy nominalnej. Użycie grupy imiennej jako nazwy gatunkowej jest charakterystyczne dla wypowiedzeń ogólnych o znaczeniu uniwersalnym (przykładem są przysłowia), jednak badania na gruncie językoznawstwa kognitywnego ${ }^{18}$ pozwoliły na dostrzeżenie w tym typie zdań aspektu typizującego, jakim jest mówienie o cechach typowego reprezentanta klasy, a w konsekwencji o całej klasie lecz z dopuszczeniem wyjątków.

Zagadnienie interpretacji generycznej zdań ogólnych, odrzucenie postulatu bezwyjątkowości przysługiwania cech oraz charakterystyka użytej w funkcji podmiotu grupy imiennej jest, jak wspomniano wyżej, przedmiotem analiz na gruncie językoznawstwa kognitywnego (G. Radden; S. Khemlani i inni; S. Prasada i inni; S.J. Leslie) ${ }^{19}$. Szczegółowy opis stanu wiedzy będącej efektem tychże badań wykracza poza zakres niniejszego artykułu. Podsumowanie wniosków Leslie oraz Prasady i in. na temat zróżnicowania zdań generycznych pod względem rodzaju predykatu (charakterystyki przypisywanej cechy) i grupy imiennej proponuje w swojej monografii Daniel Karczewski $(2016,101))^{20}$ :

\begin{tabular}{|l|l|l|l|}
\hline \multicolumn{1}{|c|}{ Przykład } & $\begin{array}{l}\text { Rodzaj predykatu wg. } \\
\text { Leslie i in. (2009) }\end{array}$ & $\begin{array}{l}\text { Rodzaj predykatu wg. } \\
\text { Prasady i in. (2013) }\end{array}$ & $\begin{array}{c}\text { Rodzaj grupy } \\
\text { imiennej }\end{array}$ \\
\hline $\begin{array}{l}\text { Tygrysy są } \\
\text { w paski } \\
\text { Tigers are } \\
\text { striped }\end{array}$ & $\begin{array}{l}\text { cecha konstytutywna } \\
\text { (principled) }\end{array}$ & $\begin{array}{l}\text { cecha reprezentatywna } \\
\text { przypisywana większości } \\
\text { (majority characteristic) }\end{array}$ & $\begin{array}{l}\text { Bare plural } \\
\text { (l.mn., nieokreślona) } \\
\text { Indefinite singular } \\
\text { (l.poj., nieokreślona) } \\
\text { Definite singular } \\
\text { (l.poj.,określona) }\end{array}$ \\
\hline
\end{tabular}

18 Zob. Günter Radden (2009), Generic reference in English: A metonymic and conceptual blending analysis, [w:] K.-Uwe Panther, red. L.L. Thornburg i A. Barcelona, Metonymy and Metaphor in Grammar, Amsterdam, John Benjamins Publishing Company, s. 199-228, za: Karczewski (2016).

19 Zob. D. Karczewski (2016)

20 Zob. Leslie, S. J. i in. (2009), Conceptual and linguistic distinctions between singular and plural generics oraz Prasada, S. i in. (2013), Conceptual distinctions amongst generics, za: Karczewski (2016). Tabela przedstawiona jest w formie zmodyfikowanej w stosunku do oryginału, z uwzględnieniem wyników eksperymentu S.J. Leslie dotyczącego interpretacji generycznej określonego rodzaju grup nominalnych. Wyniki te nie przekładają się na język polski dysponujący repertuarem dwóch form grupy nominalnej: pojedynczej i mnogiej. 


\begin{tabular}{|l|l|l|l|}
\hline \multicolumn{1}{|c|}{ Przykład } & $\begin{array}{l}\text { Rodzaj predykatu wg. } \\
\text { Leslie i in. (2009) }\end{array}$ & $\begin{array}{l}\text { Rodzaj predykatu wg. } \\
\text { Prasady i in. (2013) }\end{array}$ & $\begin{array}{c}\text { Rodzaj grupy } \\
\text { imiennej }\end{array}$ \\
\hline $\begin{array}{l}\text { Lwy mają } \\
\text { grzywy } \\
\text { Lions have } \\
\text { manes }\end{array}$ & $\begin{array}{l}\text { cecha charakterystyczna } \\
\text { (characteristic) }\end{array}$ & $\begin{array}{l}\text { cecha reprezentatywna } \\
\text { przypisywana znacznej } \\
\text { czesści } \\
\text { (minority characteristic) }\end{array}$ & $\begin{array}{l}\text { Bare plural } \\
\text { Indefinite singular } \\
\text { Definite singular }\end{array}$ \\
\hline $\begin{array}{l}\text { Samochody } \\
\text { mają radia } \\
\text { Cars have } \\
\text { radios }\end{array}$ & $\begin{array}{l}\text { cecha typowa } \\
\text { (statistical) }\end{array}$ & $\begin{array}{l}\text { cecha typowa } \\
\text { statystycznie } \\
\text { (majority statistical) }\end{array}$ & Bare plural \\
\hline $\begin{array}{l}\text { Pitbule ata- } \\
\text { kują dzieci } \\
\text { Pit bulls maul } \\
\text { children }\end{array}$ & $\begin{array}{l}\text { cecha szokująca/ } \\
\text { (striking) }\end{array}$ & $\begin{array}{l}\text { cecha szokująca/ } \\
\text { uderzająca } \\
\text { (striking) }\end{array}$ & Bare plural \\
\hline
\end{tabular}

Z danych w tabeli wynika, że w języku angielskim w przypadku cech reprezentatywnych (przysługujących większości) oraz konstytutywnej (przysługującej znacznej, lecz nie przeważającej części zbioru) jako naturalne odbierane są wszystkie trzy formy grupy nominalnej, natomiast w przypadku cech typowych (nie stanowiących o przynależności do danego zbioru) oraz uderzających (konstatowanych na podstawie nielicznych lecz wyrazistych przypadków) preferowaną formą jest bezrodzajnikowa (niekreślona) liczba mnoga.

Według Prasady i in. (2013) wypowiedzi oparte na przysługujących kategorii cechach regularnych (konstytutywnych, principled) charakteryzuje aspekt objaśniający (Fido ma cztery łapy, ponieważ jest psem), statystyczny (spodziewamy się, że większość przedstawicieli Canis Familiaris ma cztery łapy) oraz normatywny (Fido powinien mieć cztery łapy, ponieważ jest psem). Interpretacja normatywna (gdyż to ona stanowi przedmiot zainteresowania określony $\mathrm{w}$ tytule niniejszej pracy) w ostatnim przykładzie ma jednak, jak się zdaje, zupełnie inny charakter niż normatywność opisana przez Sarah-Jane Leslie (2015) w jej przełomowej pracy „Hillary Clinton is the only man in the Obama administration": Dual Character Concepts, Generics and Gender: czasownik powinien ujawniajaccy się w eksplikacji oznacza przekonanie o zgodności z pewną normą właściwą określającą cechy, których posiadanie normalnie (choć nie bezwyjątkowo) cechuje przedstawicieli grupy, nie ma natomiast typowego znaczenia powinnościowego. 


\section{Wypowiedzi generyczne o charakterze normatywnym}

Leslie (2015) rozwija powyższą intuicję w postulat, że normatywne twierdzenia generyczne określają nie normę właściwą, lecz normę idealną. Badaczka podkreśla ${ }^{21}$, że tego rodzaju wypowiedzi są nierzadko wykluczane z kategorii prawdziwych przykładów referencji gatunkowej. Jak wskazuje sam tytuł publikacji Leslie, jednym z najczęstszych kontekstów, $\mathrm{w}$ których ujawniają się predykaty generyczne przypisujące nazwom cechy charakterystyczne idealnego przedstawiciela gatunku, to wypowiedzi dotyczace kategorii płci, takie jak Chłopaki nie placza, Dziewczynki bawia sie lalkami czy Prawdziwa kobieta dba o dom. Źródłem normatywności w tego typu wypowiedziach jest, jak wskazuje Leslie (2015), różnica pomiędzy sensem deskryptywnym a opisowym rzeczownika $\mathrm{w}$ funkcji podmiotu. Swoją tezę o dychotomii normatywności/opisowości znaczeń Leslie ilustruje przykładem tytułowej Hillary Clinton. Osoba i charakterystyka Clinton osadzone są tu w kontekście dyskursu politycznego, który stereotypowo stanowi domenę mężczyzn. Opisany przez Leslie przypadek nie jest odosobniony: wystarczy przytoczyć niedawną wypowiedź posłanki Krystyny Pawłowicz na temat premier RP Beaty Szydło: Czy jedynym „mężczyzna” jest w Europie już tylko kobieta, polska premier Beata Szy$d \nmid o$ ? W sensie opisowym Clinton i Szydło są kobietami, w sensie normatywnym natomiast reprezentują one cechy normalnie przypisywane mężczyznom (zdecydowanie, siła, skuteczność). Co ciekawe, z przytoczonych przykładów wyłania się negatywna ocena mężczyzn, którym zdania te w niejawny sposób sugerują nabycie cech tradycyjnie utożsamianych z kobietami (słabość, bierność). Podobnie, maskulinizacja Hillary Clinton i Beaty Szydło w pewien sposób odbiera im prawo przynależenia do kategorii „prawdziwych kobiet”. Przykłady te wskazują, że można spełniać normatywne kryteria przynależności do kategorii nie spełniając jednocześnie warunków opisowych.

Zdania takie jak Chtopaki nie płacza, czy Prawdziwa kobieta dba o dom wykazują siłę normatywną, choć nikt nie kwestionuje faktu, że chłopcom zdarza się płakać, i że istnieją kobiety, które mają za nic dbałość o czystość i porządek. To, że chłopiec płacze a kobieta bardziej interesuje się

21 Leslie powołuje się w tym miejscu na pogląd Ariela Cohena (Cohen, A. (1999), Generics, Frequency Adverbs and Probability, "Linguistics and Philosophy”, 22, s. 221-253), cytowany w przytaczanej przez nią pracy Sally McConnell-Ginet (McConnell-Ginet S. (2012), Generic Predicates and Interest Relativity, „Canadian Journal of Linguistics" $57(2)$, s. 261-287). 
karierą niż ogniskiem domowym w żaden sposób nie oznacza, że w sensie opisowym przestają oni być przedstawicielami swojej kategorii płci, choć w sensie normatywnym nie do końca pasują do przyjętego wzorca. Wzorzec ten, jak twierdzi Leslie, ujawnia się nie tylko w kategorii płci, która - jak trafnie zauważa badaczka - jest kategorią niezwykle wyrazistą kulturowo i konotacyjnie. Można stwierdzić, że istnieje więcej tego rodzaju wyrazistych gatunków spotecznych, jak choćby matka, przyjaciel, przywódca, nauczyciel które wykazują swoistą dwoistość charakteru (ang. dual character concepts). Zjawisko pojęć o charakterze dwoistym, zbadane przez Knobego, Prasadę i Newmana (na których powołuje się Leslie), ujawnia się wyłącznie w przypadku takich gatunków społecznych, którym przypisywana jest jakaś „podstawowa rola czy funkcja, rozłączna względem deskryptywnych kryteriów przynależności do gatunku" (Leslie 2015, 114-116). Omawiana właściwość nie cechuje nazw nie plasujących się w tej kategorii, jak na przykład piekarz, taksówkarz czy kuzyn (które, choć należą do gatunków społecznych, nie są jednak wystarczająco wyraziste kulturowo). Jak podkreśla Leslie, dwoistość charakteru nie dotyczy też gatunków naturalnych. Oznacza to, że tylko w tych gatunkach społecznych, które wiążą się z pełnieniem jakiejś istotnej roli wykształcił się wzorzec idealnego przedstawiciela gatun$k u$ : dla przykładu, bycie matka czy nauczycielem wiąże się z pełnieniem ważnej społecznej roli, podczas gdy będąc kuzynem żadnej takiej funkcji spełniać nie trzeba.

Sarah-Jane Leslie dowodzi, że dychotomia normatywności/deskryptywności omawianych wypowiedzi generycznych ma swoje źródło w polisemii grupy nominalnej. Postulat ten znakomicie ilustruje przykład zdania Chłopaki nie płacza, które wyznacza normę idealną za pomocą negacji (czego nie należy robić, jakich działań nie podejmować jeśli chce się spełnić wymagania określone dla wzorca idealnego przedstawiciela kategorii). Pary wariantów w rodzaju Chłopaki nie płacza/Chłopaki płacza mogą być rozpatrywane jako zawierające $\mathrm{w}$ swojej strukturze dwie różne formy logicz$n \mathrm{e}^{22}$, lub dwa różne operatory generyczne. Takie podejście wiąże się jednak z koniecznością analizowania skomplikowanych zapisów formuł logicznych, których złożoność nie idzie w parze z poglądem, że wiedza generyczna jest z łatwością nabywana i dostępna jest nawet małym dzieciom, a zdania generyczne daja wyraz najbardziej podstawowym generalizacjom (Karczewski 2016, 19-21). Zdaniem Leslie, w obu wariantach nazwa chtopcy ma tę

22 Zob. Ariel Cohen, (2001), On the Generic Use of Indefinite Singulars, Journal of Semantics, 18(3), s. 183-209, [w:] Leslie (2015). 
samą formę ale dwa różne sensy: w Chłopaki nie płacza jest to sens normatywny, w Chłopaki płacza zaś - deskryptywny. Chłopcy, którzy z jakiegoś powodu płaczą nadal są chłopcami w sensie biologicznym (opisowym), jednak norma społeczna stanowi wyraźnie, że aby sprostać ideałowi chłopca powinni się powstrzymać od takiego wyrażania emocji (właściwego zapewne dziewczynkom), choć nie mają takiego obowiązku. Zawarta w wypowiedzi Chłopaki nie płacza norma społeczna nie oznacza, że nieokazywanie słabości (i powstrzymywanie się od płaczu) jest rzeczywiście pożądane u chłopców, nie da się jednak zaprzeczyć istnieniu siły normatywnej tak sformułowanego zdania.

\section{Podsumowanie}

Powyższe rozważania najlepiej podsumowuje konkluzja Daniela Karczewskiego, że „opis Leslie oparty jest na założeniu, że normatywne sądy generyczne formułowane są na podstawie cech charakteryzujących idealny wzorzec reprezentanta gatunku, podczas gdy deskryptywne sądy generyczne mówią o opisowych cechach typowych dla większości. W związku z tym na szczególną uwagę zasługuje fakt, że różnica między zdaniami generycznymi normatywnymi i deskryptywnymi przypomina bardziej ogólną różnicę między zdaniami generycznymi traktującymi o cechach reprezentatywnych i (statystycznie) typowych" (Karczewski 2016, 117) ${ }^{23}$. Niebagatelne znaczenie dla interpretacji normatywnych wypowiedzi generycznych ma też obecność modyfikatorów jakościowych dobry i prawdziwy ${ }^{24}$, jednak rozszerzenie zakresu dociekań o to złożone zagadnienie nie mieści się w założonych dla niniejszego artykułu ramach merytorycznych.

Analizy dotyczące (a) sposobu wyrażania norm społecznych w zdaniach ogólnych, (b) sposobu interpretacji generalizacji i wyrażeń oceniających o charakterze normatywnym, (zarówno z funktorem negacji i/lub funktorem deontycznym jak i bez), oraz (c) stopnia, w jakim wyrażone w ten sposób normy wpływają na przekonania i zachowania społeczne stanowią interesujące wyzwanie naukowe na jak dotąd słabo zbadanym (przynajmniej jeśli mowa o językoznawstwie polskim) obszarze. Badania korpusowe w zakresie

23 Z tej przyczyny w zdaniach ogólnych o charakterze normatywnym dopuszczalne są wszystkie formy grupy imiennej.

24 Więcej temat wspomnianych modyfikatorów jakościowych zob. John L. Taylor (2001): prawdziwy (real); Anna Wierzbicka (2006): prawdziwy/dobry (right/true/good); Sarah-Jane Leslie (2015): prawdziwy/dobry (real/true/good). 
omawianych struktur mogą ujawnić istotne trendy kulturowe i światopoglądowe w systemie oczekiwań związanych z określonymi rolami społecznymi, a tym samym stanowić przyczynek do włączenia językoznawstwa w nurt innych nauk poznawczych.

\section{Literatura}

Gasz A., 2013, Zarys gramatyki uogólnień na materiale aforyzmów (ujęcie polsko-rosyjskie), Katowice.

Hołówka T., 1986, Myślenie potoczne. Heterogeniczność zdrowego rozsądku, Warszawa.

Kalinowski J., 1953, Teoria zdań normatywnych. Studia Logica 1.

Kalinowski J., 1960, Teoria poznania praktycznego, Lublin.

Kalinowski J., 1993, Logika norm. Lublin.

Karczewski D., 2016, Generyczność w języku i myśleniu. Studium kognitywne, Kraków.

Kotarbiński T., 1986, Elementy teorii poznania, logiki formalnej i metodologii nauk, Warszawa.

Trypuz R., 2004, Spór o wartość logiczną norm. Logika norm a logika deontyczna, „Roczniki Filozoficzne”, LII (1), s. 293-316.

Lakoff R., 1980, Język a sytuacja kobiety, [w:] B. Stanosz (tł. i red.), Język w świetle nauki, Warszawa, s. 239-262.

Leslie S.J., 2015, „Hillary Clinton is the only man in the Obama administration”: Dual Character Concepts, Generics, and Gender, "Analytic Philosophy" Vol. 56, No. 2, s. 111-141.

Prasada S., Dillingham E., 2009, Representation of principled connections: A window onto the formal aspect of common sense conception. „Cognitive Science" $33,401-448$.

Prasada S., Khemlani S., Leslie S.-J., Glucksberg S., 2013, Conceptual distinctions amongst generics, „Cognition” 126, 405-422.

Taylor J.R., 2001, Kategoryzacja w języku, (tł.) Anna Skucińska, Universitas, Kraków, s. 111-119.

Wierzbicka, A., 2006, English: Meaning and Culture, Oxford University Press: Oxford-New York, s. 61-102.

https://plato.stanford.edu/entries/social-norms/ [02.06.2017]

http://hoga.pl/dobry-temat/chlopcy-bawia-sie-w-wojne-dziewczynki-wychowuja-la lki/ [08.06.2017]

https://www.wsensie.pl/polska/23613-pawlowicz-do-lewakow-czy-jedynym-mezczy zna-w-europie-musi-byc-kobieta-polska-premier-beata-szydlo [08.06.2017] 
THEY SAY: BOYS DON'T CRY, THEY SAY: GIRLS SHOULD BE NICE. THE QUESTION OF NORMATIVE GENERICS

\section{S U M M A R Y}

The article addresses the problem of normative reading of a certain type of general statements - namely, generics. More specifically, it attempts to present the notion of norm and normativity (in philosophical and pragmatic context) and to offer a brief semantic and syntactic description of linguistic exponents of deontic meanings. At the same time, the author draws the attention to the difference between the normative and descriptive sense of utterances. The article focuses on the way this dichotomy is related to the normative force exhibited by generics where the nominal group refers to the so-called dual character concepts. Dual character seems to arise only in the case of only such social kinds (categories) that are by widespread social agreement - expected to perform some important social role or function (e.g. a mother). It appears that the descriptive/normative duality is located in the polysemy of nouns functioning as the generic names of these kinds rather than in different logical forms. Interestingly, the fulfillment of normative criteria for an ideal (i.e. the fulfillment of social role attributed to the kind) is neither necessary nor sufficient for being a member of this kind in the descriptive sense. 